\title{
An evaluation of the effect of altering nutrition and nutritional strategies in early lactation on reproductive performance and estrous behavior of high-yielding Holstein-Friesian dairy cows
}

\author{
H. S. Gilmore, ${ }^{\star} \dagger$ F. J. Young, ${ }^{\star}$ D. C. Patterson, ${ }^{*}$ A. R. G. Wylie,‡ R. A. Law, ${ }^{11}$ D. J. Kilpatrick,‡ \\ C. T. Elliott, $\dagger$ and C. S. Mayne§ \\ ${ }^{*}$ Agri-Food and Biosciences Institute, Agriculture Branch, Hillsborough, BT26 6DR UK \\ †Queen's University of Belfast, Institute of Agri-Food and Land Use, Stranmillis Road, Belfast, BT7 1AG UK \\ $\ddagger$ Agri-Food and Biosciences Institute, Newforge Lane, Belfast, BT9 5PX UK \\ §Department of Agriculture and Rural Development for Northern Ireland, Dundonald House, Belfast, BT4 3SB UK
}

\section{ABSTRACT}

Reproductive performance in the high-yielding dairy cow has severely decreased in the last $40 \mathrm{yr}$. The aim of this study was to compare the effectiveness of 4 nutritional strategies in improving the reproductive performance of high-yielding dairy cows. It was hypothesized that offering cows a high-starch ration in early lactation would enhance the onset of luteal activity, and that decreasing the severity of negative energy balance in the early postcalving period would improve reproductive parameters. Nutritional regimens aimed at improving fertility were applied to 96 Holstein-Friesian dairy animals. Upon calving, animals were allocated in a balanced manner to one of 4 dietary treatments. Primiparous animals were balanced according to live weight, body condition score and calving date. Multiparous animals were balanced according to parity, previous lactation milk yield, liveweight, body condition score and calving date. Treatment 1 was based on an industry best practice diet (control) to contain $170 \mathrm{~g}$ of crude protein $/ \mathrm{kg}$ of dry matter. Treatment 2 was an individual cow feeding strategy, whereby the energy balance (EB) of individual animals was managed so as to achieve a predetermined target daily EB profile $( \pm 10 \mathrm{MJ} / \mathrm{d})$. Treatment 3 was a high-starch/ high-fat combination treatment, whereby an insulinogenic (high-starch) diet was offered in early lactation to encourage cyclicity and followed by a lipogenic (lowstarch, high-fat) diet to promote embryo development. Treatment 4 was a low-protein diet, containing $140 \mathrm{~g}$ of crude protein $/ \mathrm{kg}$ of dry matter, supplemented with protected methionine at an inclusion level of $40 \mathrm{~g}$ per animal per day. The nutritional strategies implemented in this study had no statistically significant effects on cow fertility measures, which included the onset of

Received June 18, 2010.

Accepted February 8, 2011

${ }^{1}$ Corresponding author: ryan.law@afbini.gov.uk luteal activity, conception rate, in-calf rate, and the incidence of atypical cycles. The individual cow feeding strategy improved EB in early lactation but had no benefit on conception rate to first insemination. However, conception rate to second insemination, 100d pregnancy rate (from the commencement of breeding), and overall pregnancy rate tended to be higher in this group. The high-starch/high-fat treatment tended to decrease the proportion of delayed ovulations and increase the proportion of animals cycling by $\mathrm{d}$ 50 postcalving. Animals that failed to conceive to first insemination had a significantly longer luteal phase in the first cycle postpartum and a longer inter-ovulatory interval in the second cycle postpartum. With regards to estrous behavior, results indicate that as the size of the sexually active group increased, the intensity of estrus and the expression of mounting or attempting to mount another cow also increased. Furthermore, cows that became pregnant displayed more intense estrous behavior than cows that failed to become pregnant.

Key words: nutrition, fertility, reproductive performance, high-yielding dairy cow

\section{INTRODUCTION}

Reproductive performance in the modern high-yielding Holstein-Friesian dairy cow has decreased at such a rate, and to such an extent, over the last $40 \mathrm{yr}$ that it is predicted that this high-performance production system will become unsustainable by 2020 if the current rate of decrease continues (Maas et al., 2009).

It is considered unlikely that this decrease in reproductive performance has a direct genetic origin, as conception rates in nonlactating Holstein-Friesian heifers have remained high (at 70-80\%) during a period when milk production has increased by $218 \%$ (Beam and Butler, 1999). However, in general, the increase in milk energy output has not been matched by a proportionate increase in energy intake, resulting in a negative energy balance (NEB), which forces, and is 
counterbalanced by, the mobilization of body reserves. Negative energy balance has been determined as an underlying causal factor of poor reproductive performance in high-yielding dairy cows (Jorritsma et al., 2003) and has been associated with a delay in the onset of luteal activity (OLA; Jolly et al., 1995), an extended interval to first service (Butler et al., 1981) and decreased conception rates (Domecq et al., 1997). Specifically, NEB impairs ovarian function through a decrease in the maximum diameter of ovarian dominant follicles (Lucy et al., 1991; Mackey et al., 1999). Smaller dominant follicles produce less estradiol, suppressing the pulsatile secretion of LH (Butler, 2001), and decreasing ovarian responsiveness to LH (Butler, 2001). Collectively, these events increase the proportion of follicles that fail to ovulate (Mackey et al., 1999).

Several diet components have the potential to influence the extent of the postpartum NEB as well as the circulating concentrations of specific blood metabolites and hormones. For example, dietary CP content has been shown to affect milk output and thereby influence NEB (Law et al., 2009a). The latter authors reported decreased milk production and improved EB in cows offered a diet of $114 \mathrm{~g}$ of $\mathrm{CP} / \mathrm{kg}$ of DM (low CP) compared with those offered $173 \mathrm{~g}$ of $\mathrm{CP} / \mathrm{kg}$ of $\mathrm{DM}$ (high $\mathrm{CP}$ ). Diets high in CP also increase blood urea concentrations (Law et al., 2009a), and Butler et al. (1996) argued that blood urea concentrations above 19 or 20 $\mathrm{mg} / \mathrm{dL}$ would result in a $20 \%$ decrease in pregnancy rate post-AI. The inclusion of protected fat in dairy cow rations increases the energy density of the diet and also has the potential to decrease the extent of the NEB (van Knegsel et al., 2007a). However, supplemental fat in excess of 50 to $60 \mathrm{~g} / \mathrm{kg}$ of DM may decrease feed intake (Schauff and Clark, 1992) and offset any potential beneficial effect on NEB. Nonetheless, the inclusion of supplemental fat is often preferred to starch inclusion, as a means of increasing the energy density of the diet, as high dietary starch levels can be detrimental to digestion, milk composition, and cow health (Staples et al., 1998). Importantly, however, diets high in starch content increase the supply of glucogenic precursors and can increase circulating insulin concentrations (van Knegsel et al., 2007b) which, in turn, are associated with enhanced cyclicity early postpartum (Gong et al., 2002). Supplementation of the diet with fat can increase cholesterol concentration (Grummer and Carroll, 1988), which serves as a precursor for progesterone synthesis (Staples et al., 1998). The inclusion of dietary fat has also proved beneficial to blastocyst growth rate in lactating dairy cows (Fouladi-Nashta et al., 2007). More recently, it has been suggested that the type of fat offered to dairy cows is more important than the quantity of fat, with particular emphasis on the effects of n-3 and n- 6 fats on reproductive performance (Childs et al., 2008). However, much of the published literature has focused on the effects of including calcium salts of palm fatty acids on dairy cow fertility (Garnsworthy et al., 2008a,b; Staples et al., 1998).

Despite the key importance of nutrition, poor reproductive performance remains multifactorial in origin with management factors also making a significant contribution. For example, a decline has occurred in the observed expression, intensity, and detection of animals in estrus (Van Eerdenburg et al., 1996; Kerbrat and Disenhaus, 2004) and poor heat detection is a major contributor to decreased reproductive performance in modern high-yielding dairy cows (Reimers et al. 1985) due to shorter and less intense estrous expression (Lopez et al., 2004). Lyimo et al. (2000) found that maximum estradiol concentrations, which are influenced by NEB, were related to total estrous expression.

The aim of the current study was to evaluate the effect of 4 distinctive nutritional regimens or strategies on the reproductive performance of contemporary highyielding Holstein-Friesian cows.

The hypotheses attached to the use of the nutritional regimens applied in the current study were as follows: (1) adjusting the protein content of individual cow diets upwards or downwards can be used to more closely align cows to an optimal and more uniform energy balance trajectory; (2) offering a high-starch diet postcalving decreases the interval from calving to the onset of luteal activity; (3) switching cows to a low-starch/ high-fat diet at $50 \mathrm{~d}$ postcalving improves reproductive parameters; and (4) offering a decreased protein ration supplemented with protected methionine decreases plasma urea concentrations in dairy cows while sustaining milk production and improving reproductive parameters.

\section{MATERIALS AND METHODS}

\section{Animals and Housing}

The experiment involved 108 Holstein-Friesian animals (40 primiparous and 68 multiparous; mean parity 2.1), calving between August 24 and December 19, 2007. Following calving, animals were housed as a single group in freestalls with concrete flooring. The cubicle-to-cow ratio was $>1: 1$ at all times, meeting the recommendations set by FAWC (1997). All cubicles had a rubber mat measuring $2.20 \mathrm{~m}$ long and $1.25 \mathrm{~m}$ wide and sawdust bedding was renewed 3 times weekly. Concrete passageway floors were scraped at least 4 times daily by an automated system. Lights were left 
on at all times. Cows were milked twice daily through a 50-point rotary parlor, commencing at 0530 and 1530 $\mathrm{h}$, with cows walking approximately $35 \mathrm{~m}$ to the parlor.

\section{Experimental Design, Diets, and Feeding}

Immediately after calving, animals were allocated to 1 of 4 dietary treatments in a balanced manner. Primiparous animals were assigned to treatments based on their live weight (LW), BCS, and calving date. Multiparous animals were assigned to treatments according to parity, previous lactation milk yield, LW, BCS, and calving date. Treatment 1 (control) reflected an industry best practice diet. It was formulated using the UK feed rationing program Feed into Milk (Thomas, 2004) and contained $170 \mathrm{~g}$ of $\mathrm{CP} / \mathrm{kg}$ of $\mathrm{DM}$ and 12.5 MJ of ME $/ \mathrm{kg}$ of DM. Treatment 2 was an individual cow feeding strategy, whereby the calculated EB of individual cows was manipulated to maintain a target daily energy balance (DEB) profile $( \pm 10 \mathrm{MJ} / \mathrm{d})$ based on that observed in cows offered $150 \mathrm{~g}$ of $\mathrm{CP} / \mathrm{kg}$ of DM (Law et al., 2009a; Figure 1). To achieve this, cows were offered $5.22 \mathrm{~kg}$ of DM of 1 of 3 concentrates differing in $\mathrm{CP}$ (via the parlor feeder), so as to achieve total dietary $\mathrm{CP}$ concentrations of $200 \mathrm{~g}$ of $\mathrm{CP} / \mathrm{kg}$ of $\mathrm{DM}$ (high), $170 \mathrm{~g}$ of $\mathrm{CP} / \mathrm{kg}$ of $\mathrm{DM}$ (medium), or $140 \mathrm{~g}$ of $\mathrm{CP} / \mathrm{kg}$ of DM (low). After calving, all animals were initially offered $170 \mathrm{~g}$ of $\mathrm{CP} / \mathrm{kg}$ of $\mathrm{DM}$ (medium) for $3 \mathrm{wk}$, after which the $\mathrm{CP}$ content of the ration was altered (if required) to dictate milk yield and subsequent DEB, until d 210 of lactation. Following any dietary adjustment, a monitoring period of $3 \mathrm{wk}$ followed before any further dietary adjustments were made. For example, if after $3 \mathrm{wk}$, the energy balance was below the target energy balance for that specific week of lactation, the $\mathrm{CP}$ content of the diet was changed from high to medium or from medium to low, depending on which diet was currently being offered. Similarly, if energy balance for the previous 3 wk was above the target, the $\mathrm{CP}$ content of the diet was increased from low to medium or medium to high, depending on which diet was currently being offered. Similarly, if energy balance for the previous 3 wk was above the target, the $\mathrm{CP}$ content of the diet was increased from low to medium or medium to high, depending on which diet was currently being offered. Treatment 3 (high-starch/high-fat), a fertility improver ration, was based on previous work by Gong et al. (2002) that had shown improved reproductive performance by feeding an insulinogenic or lipogenic diet at different stages of the reproductive cycle. In the current study, an insulinogenic (high-starch) diet was offered for $50 \mathrm{~d}$ after parturition to encourage renewed luteal activity. Then, to prevent detrimental effects of high insulin levels on oocyte quality (Fouladi-Nashta et

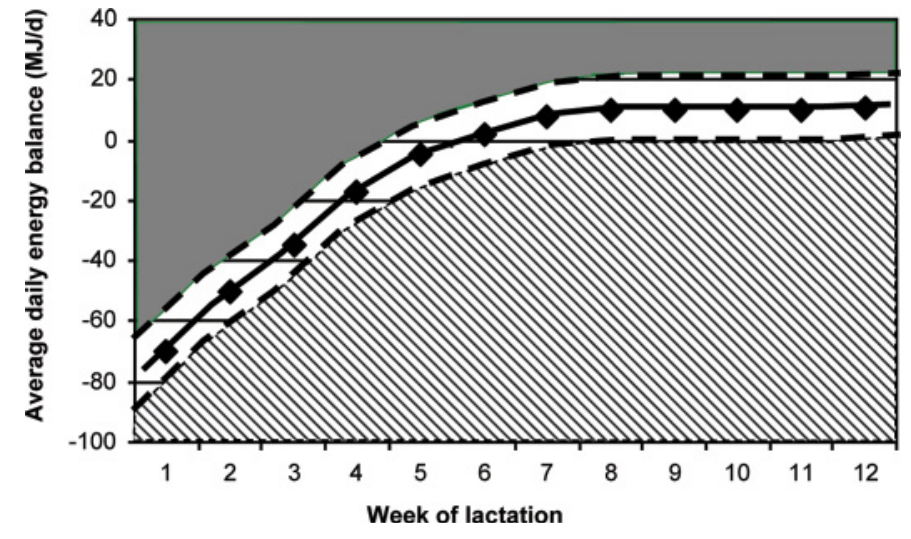

Figure 1. Example of the energy balance (EB) profile used to determine the dietary protein level offered to animals on the individual cow treatment (based on Law et al., 2009a). The solid line $(\bullet)$ illustrates the target average daily EB for each week of lactation; the dashed line (- -) illustrates the upper and lower thresholds for each week of lactation. The diagonally striped zone illustrates EB below target, whereas the solid gray zone illustrates EB above target. Color version available in the online PDF.

al., 2005), a lipogenic (low-starch/high-fat) diet, supplemented with $750 \mathrm{~g}$ of protected fat per day (as-fed basis; Megalac, calcium salts of palm fatty acids; Volac International, Royston, UK), was offered between d 51 and 120 of lactation. Treatment 4 was a low-protein diet, containing only $140 \mathrm{~g}$ of $\mathrm{CP} / \mathrm{kg}$ of DM but supplemented with protected methionine (MetaSmart; Kemin UK, Ltd., North Lincolnshire, UK) at an inclusion level of $40 \mathrm{~g}$ per animal per day. This treatment was designed to assess the effects of offering a decreased $\mathrm{CP}$ ration supplemented with protected methionine (the first limiting AA for milk production; Newbold, 2006) on the nitrogen efficiency of milk production and reproductive performance.

The concentrate-to-forage ratio of the TMR was 60:40 (DM basis) in the control, high-starch/high-fat, and low-protein treatments. Animals on the above treatments were also offered $1 \mathrm{~kg}$ of concentrate in the milking parlor each day. The individual cow TMR had a concentrate-to-forage ratio of 45:55 (DM basis) as an additional $6 \mathrm{~kg}$ (as fed) of concentrate was offered in the milking parlor daily (to facilitate the alteration of dietary $\mathrm{CP}$ content). The formulations of each of the concentrates used are presented in Table 1.

The forage component of all diets consisted of $60 \%$ grass silage and $40 \%$ maize silage (DM basis). The TMR diets were offered ad libitum and were freshly mixed each day between 1000 and 1100h. Individual DMI were recorded continuously by using feed boxes placed on computer-linked load cells with access to the boxes controlled by a gated system with electronic identifiers (Calan Inc., Northwood, NH). Feed allocation 
Table 1. Formulations $(\mathrm{g} / \mathrm{kg})$ of the concentrates used in preparing the treatments

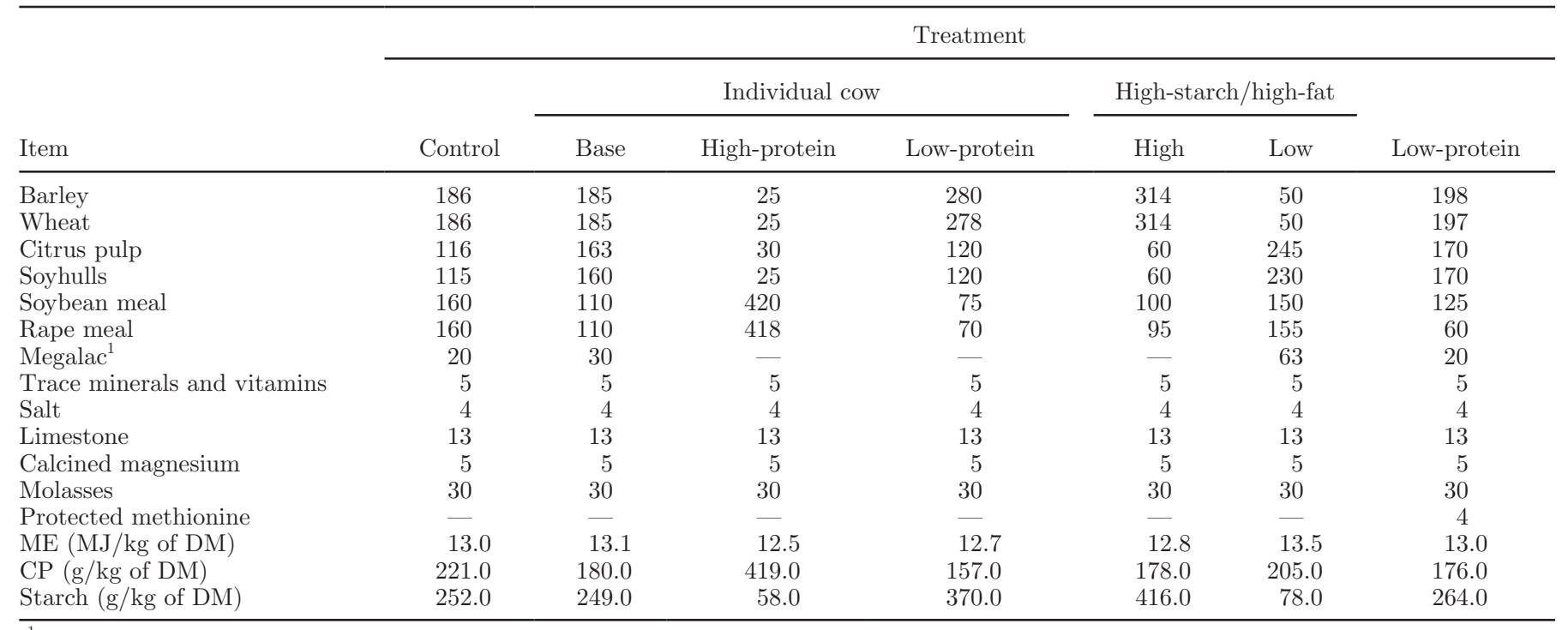

${ }^{1}$ Volac Ltd., Orwell, Hertfordshire, UK.

was calculated on a daily basis and included an excess of $10 \%$ of the total feed consumed on the previous day. An average daily intake was calculated for each animal for each week of lactation.

\section{Measurements}

Estrous behavior was observed during one 30-min period every $12 \mathrm{~h}$ at 0900 and $2100 \mathrm{~h}$ for the first 150 $\mathrm{d}$ of the breeding period (commencing November 30, 2007). Individual behavioral activities were defined according to a scoring system developed by Van Eerdenburg et al. (1996; Table 2) involving 9 key activities previously illustrated as the main behaviors expressed during estrus, each allocated an associated number of points (score). After each 30-min observational period, the total number of points scored was calculated. A total score $\geq 50$ points during a single period or consecutive observational periods (an aggregate score for a particular cycle) was taken to indicate an animal in estrus (Van Eerdenburg et al., 1996).

Milk samples for progesterone analysis were collected on Mondays, Wednesdays, and Fridays (all a.m.) from parturition until $100 \mathrm{~d}$ into the breeding period, or until confirmation of pregnancy (whichever was sooner). Milk samples were taken aseptically and to each was added a preservative tablet (Lactab Mark III; Thompson and Cooper Ltd., Runcorn, UK). Samples were stored at $4^{\circ} \mathrm{C}$ until analysis. Milk progesterone concentration was determined using a competitive ELISA kit (Ridgeway Science Ltd., Gloucestershire, UK). The assay is based on the method of Sauer et al. (1986). Pregnancy was confirmed via an ultrasound scan carried out by a veteri- narian at approximately d 30 post-insemination and by elevated milk progesterone concentrations. Animals on the control, individual cow, and low-protein treatments were inseminated as required beginning $56 \mathrm{~d}$ postcalving. Those on the high-starch/high-fat treatment were inseminated from no earlier than $71 \mathrm{~d}$ postcalving to allow at least 1 estrous cycle to occur on the high-fat diet before insemination. Breeding commenced no earlier than 56 or $71 \mathrm{~d}$ postcalving (according to treatment) and did not occur before November 30 to maintain a compact autumn-calving pattern. All inseminations were performed following the first observed estrus after the commencement of breeding. All fertility-related events were recorded. Artificial insemination was carried out $12 \mathrm{~h}$ after an observed estrus by a trained technician.

\section{Progesterone Parameter Definitions}

A full description of the methodology used to interpret and analyze the progesterone data was provided by McCoy et al. (2006). Briefly,

- the OLA is indicated by the first of at least 2 consecutive progesterone concentrations $\geq 3 \mathrm{ng} /$ $\mathrm{mL}$ in whole milk.

- the luteal phase (LP) of an individual estrous cycle is defined as the period between the first progesterone concentration $\geq 3 \mathrm{ng} / \mathrm{mL}$ and the last consecutive milk progesterone concentration $\geq 3 \mathrm{ng} / \mathrm{mL}$ in whole milk.

- the inter-ovulatory interval (IOI) is defined as the period between the first progesterone rise (above 
$3 \mathrm{ng} / \mathrm{mL}$ ) of one cycle to the first progesterone rise (above $3 \mathrm{ng} / \mathrm{mL}$ ) in the next cycle

- the inter-luteal interval (ILI) is defined as the period between the demise of one corpus luteum and the rise of the next, and is the interval from the first milk progesterone concentration $<3 \mathrm{ng} /$ $\mathrm{mL}$ to the last consecutive milk progesterone $<3$ $\mathrm{ng} / \mathrm{mL}$ in whole milk.

\section{Abnormal Progesterone Patterns}

Progesterone data was assessed according to Lamming and Darwash (1998) to characterize abnormal progesterone profiles which were:

- delayed ovulation type I (DOV I) was defined as progesterone concentration $<3 \mathrm{ng} / \mathrm{mL}$ in whole milk for $\geq 45 \mathrm{~d}$ (prolonged ovulation).

- delayed ovulation type II (DOV II) was defined as progesterone concentrations $<3 \mathrm{ng} / \mathrm{mL}$ in whole milk for $\geq 12 \mathrm{~d}$ after the OLA (prolonged inter-luteal interval).

- persistent corpus luteum type I (PCL I) was defined as progesterone concentrations $\geq 3 \mathrm{ng} /$ $\mathrm{mL}$ for $\geq 19 \mathrm{~d}$ on the first luteal phase (delayed luteolysis of the corpus luteum during the first estrous cycle).

- persistent corpus luteum type II (PCL II) was defined as progesterone concentrations $\geq 3 \mathrm{ng} / \mathrm{mL}$ for $\geq 19 \mathrm{~d}$ on subsequent luteal phases (delayed luteolysis of the corpus luteum during subsequent estrous cycles).

Several measures of reproductive performance were calculated for each cow. These included conception rate to first, second, and combined inseminations. Additionally, in-calf rates at $100 \mathrm{~d}$ and at the end of the breeding period were calculated.

Milk yield (MY) and DMI were recorded daily for each cow and average daily MY and DMI were calculated on a weekly basis for each animal. Milk composition, live weight, and BCS on a scale from 0 to 5 (Edmonson et al., 1989) were recorded weekly. Milk composition (fat, protein, and lactose content and SCC) was determined from refrigerated preserved samples (Lactab Mark III; Thompson and Cooper Ltd.) collected during 2 consecutive milkings (a.m. and p.m.) from each animal. The a.m. and p.m. samples were analyzed separately for milk fat, protein, and lactose content by infrared milk analyzer (Milkoscan FT 120, Foss UK Ltd., Warrington, UK) and milk SCC was determined using a Fossomatic 360 (Foss Electric, Hillerød, Denmark). A weighted milk composition was calculated for each week.
Table 2. The scoring scale used for observed symptoms of estrus (Van Eerdenburg et al., 1996)

\begin{tabular}{lc}
\hline Symptoms of estrus & Score $^{1}$ \\
\hline Mucous vaginal discharge & 3 \\
Cajoling & 3 \\
Restlessness & 5 \\
Sniffing the vagina of another cow & 10 \\
Chin-resting & 15 \\
Mounting (or attempting to mount) other cows & 35 \\
Mounting headside of another cow & 45 \\
Mounted but not standing immobile & 10 \\
Standing immobile on being mounted & 100 \\
\hline
\end{tabular}

${ }^{1}$ The symptom scores are cumulative.

Samples of grass silage and maize silage were analyzed daily for oven DM content. Weekly samples were subjected to near infrared reflectance spectroscopy (Park et al., 1998) for estimation of ME content. Twice weekly, fresh samples of maize silage and grass silage were analyzed for gross energy (Porter, 1992) and $\mathrm{pH}$. The same samples were also analyzed for nitrogen and ammonia nitrogen concentrations, as described by Steen (1989), and for lactic acid and VFA, ethanol, and propanol concentrations, as described by Porter and Murray (2001). Dried silage samples were prepared twice weekly and a composite 2 -wk sample was analyzed for NDF, ADF, and ash contents, as described by Cushnahan and Gordon (1995). Samples of maize silage were dried at $60^{\circ} \mathrm{C}$ twice weekly and composited 2-wk samples were analyzed for starch using the Megazyme kit (K-TSTA; Megazyme International Ireland Ltd., Co. Wicklow, UK; procedure detailed at http://www. megazyme.com/booklets/KTSTA.pdf). Each batch of concentrate was sampled and composite 2-wk samples were analyzed for oven $\mathrm{DM}$ content $\left(\right.$ at $\left.60^{\circ} \mathrm{C}\right)$. Dried samples were analyzed for nitrogen (Steen, 1989), ADF, NDF, and ash concentrations, as described by Cushnahan and Gordon (1995) and were bulked for starch analysis by the Megazyme kit.

Blood samples were collected weekly between 0930 and $1130 \mathrm{~h}$ from the coccygeal vein of all cows using heparin-coated evacuated tubes (Becton Dickson, Oxford, UK) from calving until d 100 of lactation, and then every 2 wk thereafter. Plasma was recovered and stored at $-20^{\circ} \mathrm{C}$ pending urea analysis using an Olympus AU640 autoanalyzer (Olympus Life and Materials Science, Hamburg, Germany).

\section{Calculation of Energy Balance}

The average DEB for each animal was calculated for each week of lactation according to Thomas (2004) as follows: 


$$
\begin{gathered}
\mathrm{DEB}=\mathrm{ME} \text { intake }-\mathrm{ME} \text { requirement }\left[-10+\left(\mathrm{ME}_{\text {preg }}\right.\right. \\
\left.\left.\left.+\mathrm{ME}_{\text {maintmilk }} \times \mathrm{LW}^{0.75}\right)\right]+[(0.0013 \times \mathrm{LW}) / \mathrm{Km})\right],
\end{gathered}
$$

where $\mathrm{ME}_{\text {preg }}$ is the $\mathrm{ME}$ requirement for pregnancy, $\mathrm{ME}_{\text {maintmilk }}$ is the combined $\mathrm{ME}$ requirement for maintenance and milk production, and Km (efficiency of energy use for maintenance) $=0.35 \times \mathrm{ME} / \mathrm{GE}+0.503$. Milk yield, DMI, milk composition, LW, and feed composition data were all used in the calculations. Missing values (fewer than 2 percent of all data) were estimated from data for the week before, and the week following.

\section{Statistical Analysis}

All statistical analysis was performed using Genstat (Payne et al., 2007). Data were analyzed by a repeated measures approach using the residual maximum likelihood (REML) procedure. The model fitted fixed effects for parity, postcalving treatment, and week of lactation for each parameter and included all second- and thirdlevel interactions between these variables. Within the model, individual animals represented subjects and week of lactation represented time points that were equally spaced and the same for all animals. As the correlations between successive measurements on the same subject were assumed to decrease with time with the interval between successive time points being $1 \mathrm{wk}$, an autoregressive error correlation model of order 1 was used.

Linear regression analysis was performed to examine the effects of production and metabolic parameters (independent variables) on all reproduction-related variables. The independent variables used in the multiple linear regression analysis were MY, milk energy concentration, daily $\mathrm{EB}$, cumulative $\mathrm{EB}$, average $\mathrm{DEB}$ in wk 1 to 3 of lactation, average DEB in wk 1 to 6 of lactation, and the number of weeks to the EB nadir. A logistic regression model was used to analyze conception rate (CR) to first service, CR to second service, CR to first and second services, $100 \mathrm{~d}$ in-calf rate, DOV types I and II, PCL types I and II, and whether or not more than 1 abnormal progesterone profile was observed. When assessing treatment effects, voluntary waiting period was included as a covariate in the analysis. Animals on the control, individual cow, and low-protein treatments had a voluntary waiting period of $56 \mathrm{~d}$ postcalving, whereas animals on the high-starch/high-fat treatment had a voluntary waiting period of $71 \mathrm{~d}$.

Estrous behavior data were not normally distributed and, therefore, a square root transformation was applied before analysis to normalize the data.

In total, 16 animals were removed from the study over the duration of the experiment due to ill health, injury, or death.

\section{RESULTS}

\section{Nutritional Composition}

The nutritional composition of the diets offered in the current study are presented in Table 3 . The control diet had a starch content of $177 \mathrm{~g}$ and a protein content of $185 \mathrm{~g}$ of $\mathrm{CP} / \mathrm{kg}$ of DM. The starch contents of the basal (0-35 d postpartum), high- (35-50 d postpartum), and low-starch diets offered as part of the high-starch/ high-fat treatment were 177, 273, and $97 \mathrm{~g}$ of starch/ $\mathrm{kg}$ of DM respectively. The dietary protein contents of the rations offered to animals on the individual cow treatment were 205,181 , and $156 \mathrm{~g}$ of $\mathrm{CP} / \mathrm{kg}$ of $\mathrm{DM}$ for high-, medium-, and low-protein rations. The $\mathrm{CP}$ content of the low protein diet was $163 \mathrm{~g} / \mathrm{kg}$ of $\mathrm{DM}$ and the starch content was $187 \mathrm{~g}$ of $\mathrm{CP} / \mathrm{kg}$ of DM. Metabolizable energy contents for the rations were similar across all treatments $(12.2-12.5 \mathrm{MJ} / \mathrm{kg}$ of $\mathrm{DM})$.

\section{Production Performance}

Animals allocated to the individual cow treatment had higher average DMI $[P<0.001$; standard error of differences (SED), 0.32], total ME intake $(P<0.001$; SED, 0.08), grass silage DMI $(P<0.001$; SED, 0.05), and maize silage DMI $(P<0.001$; SED, 3.69) compared with those allocated to the other treatments (Table 4). Mean concentrate DMI was not different between treatments $(P>0.05)$. Milk yield and milk fat and milk protein concentrations were not affected $(P>0.05)$ by dietary treatment. Across all treatments, the average milk yield was $32.8 \mathrm{~kg} / \mathrm{d}$, milk fat concentration was $38.4 \mathrm{~g} / \mathrm{kg}$, and milk protein concentration was $33.7 \mathrm{~g} /$ $\mathrm{kg}$ during the first $210 \mathrm{~d}$ of lactation. Neither LW nor BCS during the first $210 \mathrm{~d}$ of lactation were affected by dietary treatment $(P>0.05)$. A statistically significant $(P=0.015$; SED 0.675$)$ interaction was observed between stage of lactation and treatment effects for milk protein content; however, no statistically significant relationships were identified for other production variables.

\section{Plasma Metabolites}

Milk urea concentrations were lower in animals offered the low-protein treatment $(P<0.001)$ compared with those offered the control, individual cow, and high-starch/high-fat treatments (133.6 g/kg vs. 164.3, 174.0 , and $158.2 \mathrm{~g} / \mathrm{kg}$, respectively). Mean plasma urea concentrations differed $(P<0.001)$ between the lowprotein treatment $(11.0 \mathrm{mg} / \mathrm{dL})$ and control, individual cow management, and high-starch/high-fat treatments (14.1, 14.1, and $14.7 \mathrm{mg} / \mathrm{dL}$, respectively). 
Table 3. Key nutritional components of the total diet for each nutritional treatment ${ }^{1}$

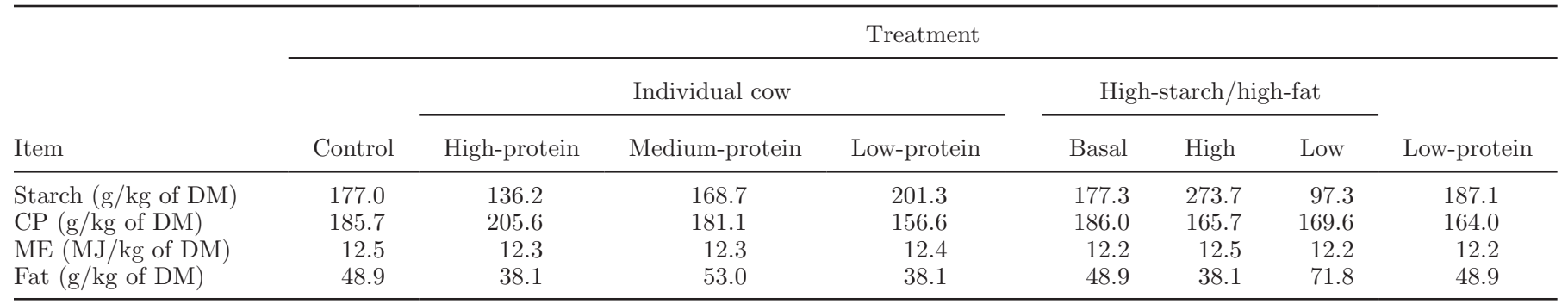

${ }^{1}$ The treatment diets refer to the TMR and include any concentrates fed in the parlor.

\section{Energy Status}

Overall, mean daily EB during the first $210 \mathrm{~d}$ of lactation was higher $(P<0.001)$ in animals allocated to the individual cow treatment $(31.7 \mathrm{MJ} / \mathrm{d})$ than in cows offered the control, high-starch/high-fat, or low-protein treatments $(18.5,18.8$, and $13.1 \mathrm{MJ} / \mathrm{d}$, respectively; Figure 2). Animals allocated the individual cow treatment had established a positive EB by wk 4 postpartum, whereas animals on the control, high-starch/high-fat, and low-protein treatments entered positive EB only in wk 5,8 , and 8 postpartum, respectively. Cumulative EB was higher $(P=0.001)$ in animals allocated to the individual cow treatment (6657 MJ) than in those allocated the control, high-starch/high-fat, or low-protein treatments $(3,874,3,958$, and 2,740 MJ, respectively).

\section{Fertility Parameters}

Conception rate to first or second, or first and second service combined was not affected $(P<0.05)$ by nutritional treatment (Table 5) at 30.5\% (SED, 9.5), 41.7\% (SED, 12.2), and 58.8\% (SED, 10.2) respectively. Animals allocated to the individual cow treatment had a lower $(P>0.05) \mathrm{CR}$ to first insemination $(24 \%)$ than did those receiving the control, high-starch/high-fat, and low-protein diets $(33.3,36.0$, and $28.5 \%$, respectively). Conversely, the CR to second service of animals allocated to the individual cow treatment was higher $(P>0.05)$ than in those allocated to the other treatments (52.6 vs. $42.9,31.3$, and $40.0 \%$, respectively). No statistically significant correlation between EB and CR in the current study. Voluntary waiting period had no significant effect on any of the parameters analyzed.

Nutritional treatment had no effect on CR during the first $100 \mathrm{~d}$ of the breeding period or throughout the entire 6-mo breeding season (both $P>0.05$; Table 5). However, animals offered the individual cow treatment had slightly improved $100 \mathrm{~d}$ in-calf rate and higher CR at the end of the breeding season, although neither of these variables was statistically significant. The 100 d in-calf rate and overall CR of animals offered the individual cow treatment, the control treatment, the high-starch/high-fat treatment, and the low-protein treatments were 79.2 and $95.8 \%, 71.4$ and $85.7 \%, 68.0$ and $88.0 \%$, and 71.4 and $81.0 \%$, respectively.

\section{Luteal Activity Characteristics (by Milk Progesterone Concentrations)}

Nutritional treatment had no effect $(P>0.05)$ on the interval to the OLA, or on the durations of the

Table 4. Treatment effects on milk production and energy balance between 1 and $210 \mathrm{~d}$ of lactation

\begin{tabular}{|c|c|c|c|c|c|c|c|}
\hline \multirow[b]{2}{*}{ Item } & \multicolumn{4}{|c|}{ Treatment } & \multirow[b]{2}{*}{$\mathrm{SED}^{1}$} & \multicolumn{2}{|c|}{$P$-value } \\
\hline & Control & $\begin{array}{l}\text { Individual } \\
\text { cow }\end{array}$ & $\begin{array}{c}\text { High-starch/ } \\
\text { high-fat }\end{array}$ & Low-protein & & Treatment & $\begin{array}{l}\text { Treatment } \\
\quad \times \text { DIM }\end{array}$ \\
\hline Milk yield ( $\mathrm{kg} / \mathrm{d})$ & 32.8 & 32.7 & 33.3 & 32.6 & 1.14 & 0.707 & 0.108 \\
\hline Milk fat $(\mathrm{g} / \mathrm{kg})$ & 37.7 & 39.4 & 38.6 & 38.1 & 0.72 & 0.198 & 0.494 \\
\hline Milk protein (g/kg) & 33.8 & 33.9 & 33.6 & 33.7 & 0.38 & 0.984 & 0.015 \\
\hline Milk urea $(\mathrm{mg} / \mathrm{kg})$ & 164 & 174 & 158 & 134 & 2.9 & 0.001 & 0.285 \\
\hline Mean live weight (kg) & 563 & 557 & 565 & 566 & 15.4 & 0.861 & 0.959 \\
\hline DMI $(\mathrm{kg} / \mathrm{d})$ & 19.7 & 21.0 & 19.7 & 19.3 & 0.32 & 0.001 & 0.752 \\
\hline Concentrate DMI (kg/d) & 12.2 & 12.3 & 12.2 & 11.9 & 0.17 & 0.458 & 0.495 \\
\hline Grass silage DMI (kg/d) & 4.5 & 5.3 & 4.5 & 4.4 & 0.82 & 0.001 & 0.166 \\
\hline Maize silage DMI (kg/d) & 3.0 & 3.5 & 3.0 & 3.0 & 0.05 & 0.001 & 0.166 \\
\hline Total ME (MJ/d) & 249 & 265 & 251 & 244 & 3.7 & 0.001 & 0.717 \\
\hline $\mathrm{DEB}^{2}(\mathrm{MJ} / \mathrm{d})$ & 18.4 & 31.7 & 18.8 & 13.1 & 3.62 & 0.001 & 0.429 \\
\hline
\end{tabular}

${ }^{1}$ Standard error of differences.

${ }^{2}$ Daily energy balance. 


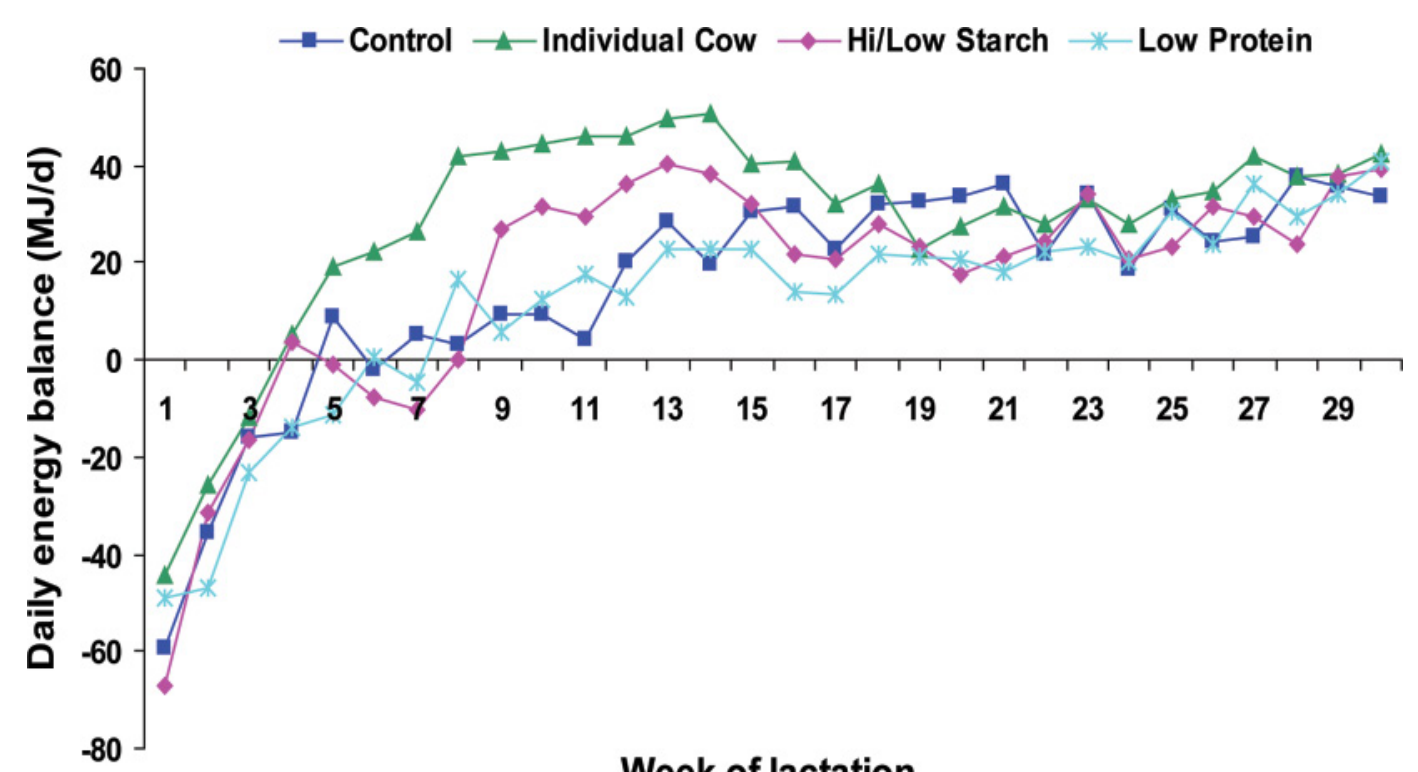

\section{Week of lactation}

Figure 2. Effects of treatments on daily energy balance between calving and $210 \mathrm{~d}$ of lactation $(P<0.001$, standard error of differences $=$ 3.62). Color version available in the online PDF.

luteal phase, inter-ovulatory interval, or inter-luteal interval (Table 5). However, although not statistically significant, the low-protein and high-starch/high-fat treatments had the greatest proportions of animals cycling by $30 \mathrm{~d}$ postpartum ( 81.0 and $73 \%$, respectively), whereas the control treatment and individual cow treatment achieved only 54 and $67 \%$, respectively. By $40 \mathrm{~d}$ postpartum, 85.7 and $84.6 \%$ of cows on the low-protein and high-starch/high-fat treatments were cycling compared with 75.0 and $77.8 \%$ of those on the control and individual cow treatments.

Parity had a statistically significant effect on the duration of the IOI with multiparous animals having a longer IOI than primiparous animals $(24.2$ vs. $21.3 \mathrm{~d}$; $P<0.05)$. However, parity did not affect $(P>0.05)$ either the interval to OLA, or the duration of the LP or ILI. The LP was shorter $(P<0.001)$ in the first cycle postpartum than in either the second or third cycles (10.9 d vs. 14.2 and $14.8 \mathrm{~d}$, respectively) but was unaffected by parity or nutritional treatment (Table 6 ) . The IOI and ILI were not different between cycles $(P$ $>0.05)$.

In the first cycle postpartum, the duration of the LP was greater $(P<0.05)$ in animals that did not become pregnant at either the first or second services when compared with animals that became pregnant (12.6 vs. $9.5 \mathrm{~d}$; SED, 1.43). The length of the second cycle postpartum was greater $(P<0.05)$ in animals that did not become pregnant at the first AI postpartum than in those that became pregnant ( 25.3 vs. 21.3 $\mathrm{d}$, respectively; SED, 2.70). The length of the second cycle postpartum tended to be greater $(P=0.062)$ in animals that were not pregnant by $100 \mathrm{~d}$ after the commencement of breeding than in those that were pregnant (26.4 vs. 22.9 d, respectively; SED, 2.62). In the third cycle postpartum, the ILI was greater $(P<$ $0.05)$ in animals that were not pregnant by $100 \mathrm{~d}$ after the commencement of breeding than in animals that were pregnant (6.0 vs. 4.6 d, respectively; SED, 0.68). Compared with pregnant animals, those that were not pregnant by the end of the breeding period had a longer third cycle IOI ( 26.3 vs. 22.3 d; $P<0.05$; SED, 3.78) and ILI (5.8 vs. $4.7 \mathrm{~d} ; P<0.01 ;$ SED, 1.30$)$.

\section{Atypical Progesterone Profiles}

Across all treatments, $62.2 \%$ (SEM 14.0) of animals displayed at least one atypical progesterone profile (Table 5). Within this average figure, animals subjected to the individual cow treatment had the highest proportion displaying one or more atypical profiles (81.5\%), whereas $57.6,58.3$, and $47.6 \%$ of cows on the highstarch/high-fat, control and low-protein treatments, respectively, displayed 1 or more atypical profiles, but treatment did not significantly affect the proportion of animals exhibiting at least 1 atypical cycle.

No effect of treatment was observed on the incidences of DOV I or DOV II $(P>0.05)$, which were observed in 12.5 and $16.3 \%$ of cycles, respectively, across all nutritional treatments. The incidences of PCL I or PCL 
Table 5. Treatment effects on conception rate and estrous cycle characteristics

\begin{tabular}{|c|c|c|c|c|c|c|}
\hline \multirow[b]{2}{*}{ Item } & \multicolumn{4}{|c|}{ Treatment } & \multirow[b]{2}{*}{$\mathrm{SED}^{1}$} & \multirow[b]{2}{*}{$P$-value } \\
\hline & Control & $\begin{array}{l}\text { Individual } \\
\text { cow }\end{array}$ & $\begin{array}{c}\text { High-starch/ } \\
\text { high-fat }\end{array}$ & Low-protein & & \\
\hline Voluntary waiting period (d) & 56 & 56 & 71 & 56 & - & - \\
\hline Interval from calving to conception (d) & 134.0 & 127.9 & 150.0 & 142.0 & 13.5 & 0.548 \\
\hline Conception rate to first insemination (\%) & 33.3 & 24.0 & 36.0 & 28.5 & 9.5 & 0.805 \\
\hline Conception rate to second insemination (\%) & 42.9 & 52.6 & 31.3 & 40.0 & 12.2 & 0.641 \\
\hline Conception rate to first and second inseminations (\%) & 61.9 & 60.0 & 56.0 & 57.1 & 10.2 & 0.977 \\
\hline In-calf rate at $100 \mathrm{~d}$ of the breeding period $(\%)$ & 71.4 & 79.2 & 68.0 & 71.4 & 9.3 & 0.841 \\
\hline In-calf rate at the end of the breeding period (\%) & 85.7 & 95.8 & 88.0 & 81.0 & 6.9 & 0.430 \\
\hline Onset of luteal activity (d) & 31.5 & 26.1 & 21.7 & 25.5 & 6.54 & 0.648 \\
\hline Proportion of animals cycling by $30 \mathrm{~d}$ postpartum (\%) & 54.2 & 66.7 & 73.1 & 81.0 & 18.3 & 0.756 \\
\hline Proportion of animals cycling by $40 \mathrm{~d}$ postpartum (\%) & 75.0 & 77.8 & 84.6 & 85.7 & 15.4 & 0.648 \\
\hline Proportion of animals cycling by $50 \mathrm{~d}$ postpartum (\%) & 87.5 & 81.5 & 92.3 & 85.7 & 12.9 & 0.715 \\
\hline Luteal phase (d) & 12.6 & 14.1 & 14.3 & 12.4 & 1.21 & 0.252 \\
\hline Inter-ovulatory interval (d) & 22.6 & 23.9 & 22.3 & 22.2 & 1.74 & 0.552 \\
\hline Inter-luteal interval $(\mathrm{d})$ & 6.2 & 5.8 & 5.0 & 5.8 & 1.55 & 0.595 \\
\hline Delayed ovulation type $\mathrm{I}^{2}(\%)$ & 12.5 & 18.5 & 8.0 & 17.0 & 8.58 & 0.979 \\
\hline Delayed ovulation type $\mathrm{II}^{2}(\%)$ & 25.0 & 15.4 & 8.0 & 16.7 & 8.01 & 0.170 \\
\hline Persistent corpus luteum type $\mathrm{I}^{2}(\%)$ & 4.2 & 26.9 & 16.7 & 17.6 & 5.61 & 0.089 \\
\hline Persistent corpus luteum type $\mathrm{II}^{2}(\%)$ & 25.0 & 46.2 & 44.0 & 22.2 & 8.93 & 0.819 \\
\hline Animals with one or more atypical cycles (\%) & 58.3 & 81.5 & 57.6 & 47.6 & 18.5 & 0.281 \\
\hline
\end{tabular}

${ }^{1}$ Standard error of differences. ${ }^{2}$ Percentage of cycles that were atypical. 
Table 6. Effects of cycle number postcalving on estrous cycle parameters

\begin{tabular}{|c|c|c|c|c|c|}
\hline \multirow[b]{2}{*}{ Item } & \multicolumn{3}{|c|}{ Cycle number postcalving } & \multirow[b]{2}{*}{$\mathrm{SED}^{1}$} & \multirow[b]{2}{*}{$P$-value } \\
\hline & 1 & 2 & 3 & & \\
\hline Luteal phase (d) & 10.94 & 14.4 & 14.78 & 0.911 & 0.001 \\
\hline Inter-ovulatory interval (d) & 21.07 & 24.16 & 23.04 & 1.725 & 0.177 \\
\hline Inter-luteal interval (d) & 6.08 & 6.05 & 5.01 & 1.169 & 0.476 \\
\hline
\end{tabular}

${ }^{1}$ Standard error of differences.

II were not affected $(P>0.05)$ by nutritional strategy and occurred in 16.4 and $34.4 \%$ of cycles, respectively (Table5).

\section{Estrous Behavior}

In the current study, an estrus detection rate of $85.5 \%$ was achieved when recording commenced at the start of breeding and continued to $150 \mathrm{~d}$ of lactation. Dietary treatment had no statistically significant effect on the expression of individual estrous behaviors or the total estrous score for each animal (Table 7). An increase in the size of the sexually active group (the number of animals in estrus simultaneously) increased $(P<0.01)$ the total estrous score $(163,356,307,381$, and 445 for sexually active group sizes of $1,2,3,4$, or 5 or more animals, respectively; SED, 77.1; Table 8). No statistically significant effect of nutritional treatment on the size of the sexually active group was found. The size of the sexually active group had an effect on the incidence of mounting or attempted mounting of other cows $(P<0.05$; SED, 1.95) and the incidence of standing immobile on being mounted $(P<0.01$; SED, 2.47). Chin-resting and sniffing the vagina of another cow were expressed most frequently during the observation periods ( 89.0 and $88.1 \%$, respectively). The behavior of mounting, or attempted mounting of another cow was expressed in $81.6 \%$ of all heats. Standing immobile on being mounted was observed in only $47.4 \%$ of all heats.

A parity $\times$ nutritional treatment interaction was observed for standing immobile on being mounted $(P<$
0.01; SED, 1.22). Standing immobile on being mounted was expressed more frequently by primiparous animals in the high-starch/high-fat and low-protein treatment groups than in either the control or individual cow management groups. However, standing immobile on being mounted was expressed more frequently in multiparous animals offered the control and individual cow treatments compared with the high-starch/high-fat and low-protein treatments.

The total estrous score was associated with conception success $(P<0.001$; Table 9$)$, with animals that conceived having a higher total estrous score than animals that did not conceive (406 vs. 201; SED, 39.9) and multiparous animals had a tendency to achieve higher total estrous scores than did primiparous animals $(P=$ 0.062 ).

Logistic regressions were performed on variables, including daily EB, cumulative EB, and blood metabolite concentrations against conception rates but no statistically significant differences were observed.

\section{DISCUSSION}

The aim of the current study was to assess the effectiveness of 4 nutritional strategies in improving the fertility of high-yielding dairy cows.

\section{High-Starch/High-Fat (Treatment 2)}

The high-starch/high-fat treatment was designed to influence plasma insulin concentrations such that, in

Table 7. Treatment effects on the expression of estrous behaviors and total score (following a square root transformation)

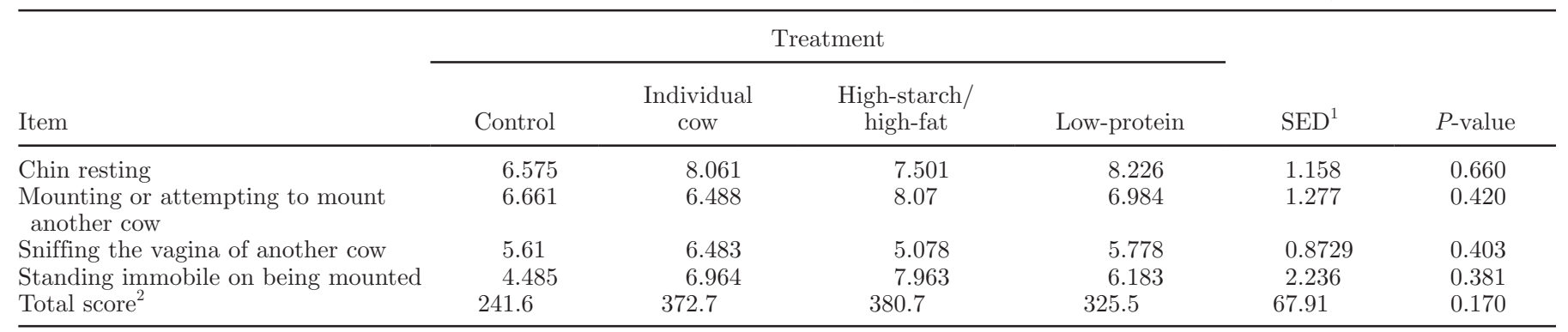

${ }^{1}$ Standard error of differences.

${ }^{2}$ Total score did not undergo square root transformation. 
Table 8. Effects of the size of the sexually active group on the expression of estrous behaviors (following a square root transformation)

\begin{tabular}{|c|c|c|c|c|c|c|c|}
\hline $\begin{array}{l}\text { Behavioral } \\
\text { activity }\end{array}$ & \multicolumn{5}{|c|}{ Size of the sexually active group (n) } & $\mathrm{SED}^{1}$ & $P$-value \\
\hline Chin resting & 6.563 & 7.264 & 6.599 & 9.383 & 8.144 & 1.32 & 0.086 \\
\hline Sniffing the vagina of another cow & 6.509 & 5.426 & 5.345 & 5.826 & 5.579 & 0.959 & 0.406 \\
\hline Standing immobile on being mounted & 0.795 & 8.344 & 7.408 & 6.996 & 8.452 & 2.467 & 0.007 \\
\hline Total score $^{2}$ & 162.9 & 356.0 & 306.7 & 380.7 & 444.5 & 77.07 & 0.006 \\
\hline
\end{tabular}

${ }^{1}$ Standard error of differences.

${ }^{2}$ Total score did not undergo square root transformation.

early lactation (calving to $50 \mathrm{~d}$ postcalving), the highstarch option would favor elevated insulin, thereby enhancing ovarian follicle development and decreasing the interval to OLA. Gong et al. (2002) illustrated that including $260 \mathrm{~g}$ of starch $/ \mathrm{kg}$ of diet DM (high-starch) increased the proportion of dairy cows ovulating by 50 $\mathrm{d}$ postpartum and decreased the interval from calving to first ovulation. van Knegsel et al. (2007a) also found that multiparous cows offered a high-starch diet tended to have an earlier OLA than animals offered diets with lower starch contents. However, Garnsworthy et al. (2009) reported a delay in OLA in cows offered a high-starch diet (182 $\mathrm{g}$ of starch $/ \mathrm{kg}$ of $\mathrm{DM}$ ) compared with those offered a low-starch diet (98 g of starch/ $\mathrm{kg}$ of DM) although, in this study, the time difference was not statistically significant. In the current study, the low-protein and high-starch/high-fat treatments tended to have the greatest proportions of cows cycling by $30 \mathrm{~d}$ postpartum (0.81 and 0.73 , respectively). In the current study also, the average interval to OLA was $33 \mathrm{~d}$ in animals offered the high-starch/high-fat treatment, which is comparable to the values of $31.6 \mathrm{~d}$ reported for multiparous cows fed high-starch diets by Garnsworthy et al. (2009). van Knegsel et al. (2007a) reported an interval to OLA of 20.4 and $31.7 \mathrm{~d}$ in multiparous and primiparous cows, respectively, whereas Gong et al. (2002) reported an interval to OLA of 41.4 and $27.5 \mathrm{~d}$ in cows of high genetic merit and low genetic merit, respectively.

High plasma insulin levels are detrimental to oocyte quality in cows (Fouladi-Nashta et al., 2005) and heifers (Adamiak et al., 2005, 2006), explaining the reason for the switch from a high-starch (insulinogenic) formu- lation to a low-starch (non-insulinogenic) formulation within treatment 2. The low-starch formulation was made lipogenic by supplementation with $750 \mathrm{~g} / \mathrm{d}$ of protected fat in an effort to further encourage follicular development and corpus luteum formation between d 50 to 120 of lactation, as suggested by Gong et al. (2002). A decrease in oocyte quality will suppress the potential for oocyte development and decrease the blastocyst count post-fertilization (Fouladi-Nashta et al., 2005). Recently, Garnsworthy et al. (2009) reported higher pregnancy rates by d 120 postpartum in cows offered a high-starch diet until the time of the first rise in milk progesterone and then switched to a low-starch diet than in cows offered a low-starch diet followed by a high-starch diet, a high-starch diet throughout, or a low-starch diet throughout. In the current study, the high-starch/high-fat treatment had no effect on conception rate to first service, $100 \mathrm{~d}$ in-calf rate, or the incidence of atypical progesterone profiles. One explanation for the different results between studies could be that a high-starch diet was continued after the OLA in the current experiment, which may have had detrimental effects on the potential for oocyte development post-insemination.

In the current study, no statistically significant effect of treatment on conception rate to first service existed when data from multiparous animals were analyzed separately. However, a tendency existed for multiparous animals on the high-starch/high-fat treatment to have a higher conception rate to first service $(52.9 \%)$ relative to controls $(25.0 \%)$. This was greater also than the $38 \%$ conception rate to first service observed by Garnsworthy et al. (2009) for a similar experimental treatment.

Table 9. Effects of total estrous score on conception

\begin{tabular}{lcccc}
\hline Parity & Pregnant & $\begin{array}{c}\text { Not } \\
\text { pregnant }\end{array}$ & SED $^{1}$ & $P$-value \\
\hline All & 406.4 & 201.3 & 39.88 & 0.001 \\
Primiparous & 329.9 & 199.6 & 54.65 & 0.062 \\
Multiparous & 483.0 & 203.1 & &
\end{tabular}

${ }^{1}$ Standard error of differences. 
In the current study, treatment groups consisted of 27 cows. Due to reasons unrelated to experimental procedures, 16 animals were removed at various stages during the study. Using the calculations of Morris (2002) for the analysis of continuous data with a normal distribution, and assuming a coefficient of variation of $17 \%$, 26 animals per treatment would be required to detect a significant difference of $12 \%$ between treatments (at the $95 \%$ confidence level). However, for data with a binomial distribution, the assessment of treatment effects would have required 267 animals per treatment to detect a $12 \%$ difference in $\mathrm{CR}$ at the $95 \%$ confidence level and with an experimental power of 0.8 (Thrusfield, 2005). Such numbers of cows were beyond the resources available for the current study.

\section{Individual Cow Management (Treatment 3)}

In the individual cow treatment, the variation in $\mathrm{EB}$ within treatment was significantly decreased between wk 2 and 8 postcalving (Figure 3). In wk 2 postpartum, no difference in average DEB between diets was observed; however, by wk 8 postpartum, all animals on this treatment had reached positive DEB and the degree of variation in DEB within the treatment was much less than that in other treatments, resulting in a more energetically uniform group of animals.

Overall, animals on the control treatment had the greatest variation in EB. Although the effect was not statistically significant, cows on the individual cow treatment tended to have better reproductive performance (conception rate to first and second service and $100 \mathrm{~d}$ in-calf rate) which may have been due to a higher proportion of animals being in positive EB earlier in lactation. It is hypothesized that the developmental and steroidogenic competence of follicles is decreased by exposure to a metabolically challenging period such as that presented by NEB during the long period of follicular growth (Britt, 1992; Roth et al., 2001). Furthermore, the oocytes within such follicles, which ovulate 60 to 80 d later, may be inferior (Leroy et al., 2010). However, animals on the individual cow treatment tended to have a lower conception rate to first insemination despite their generally improved energy status. The observed tendency for an improved conception rate to second insemination in animals on the individual cow treatment may be a reflection of successful ovulation of a good quality oocyte that has been recruited
Daily energy balance week 2

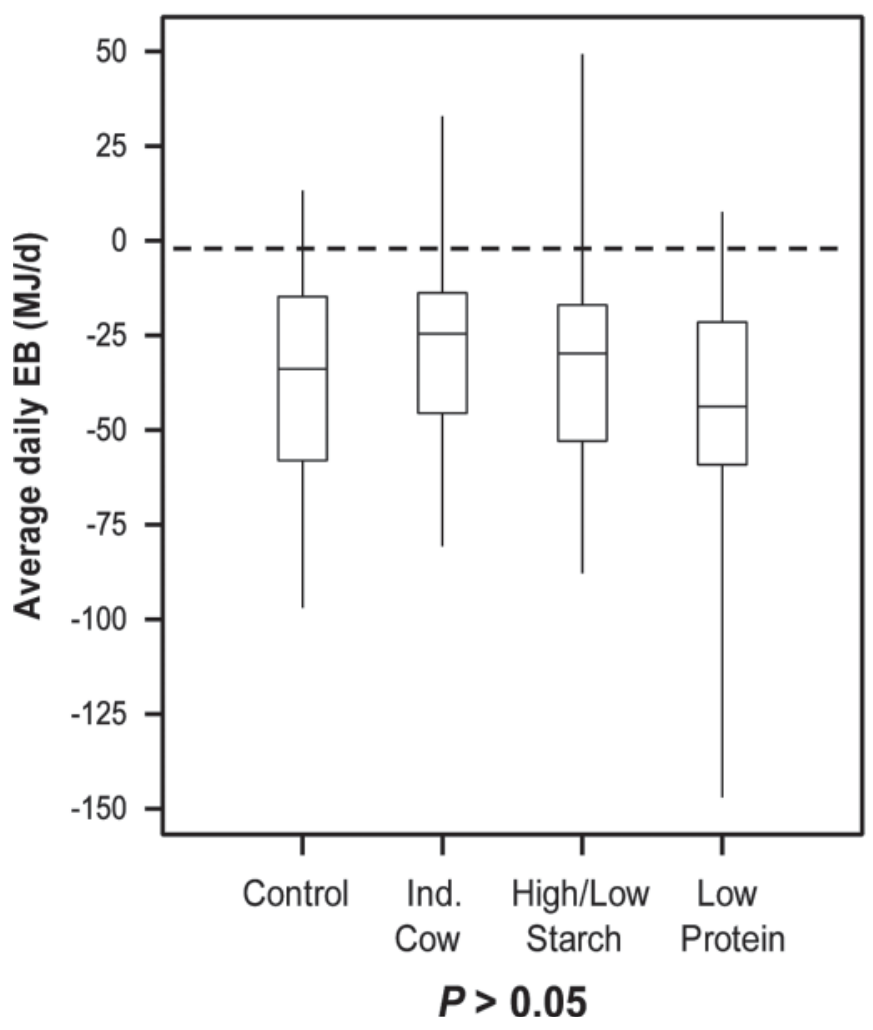

\section{Daily energy balance week 8}

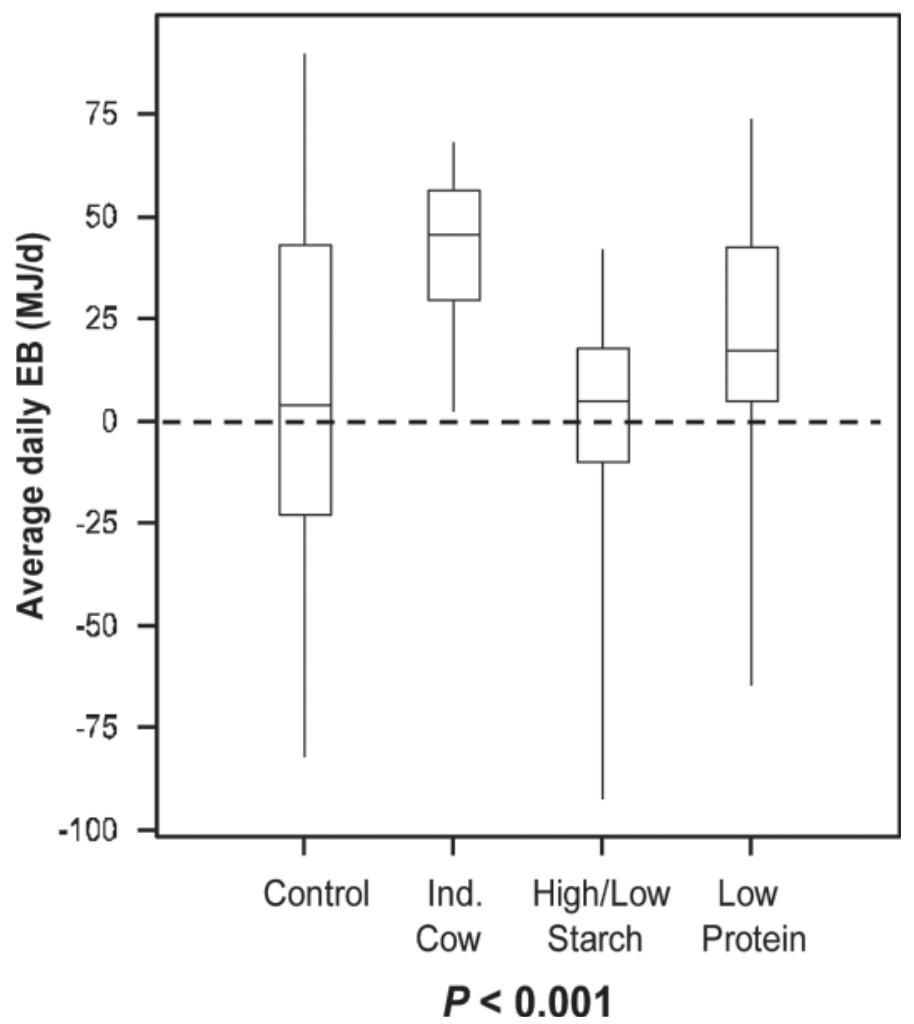

Figure 3. Average daily energy (EB) balances during wk 2 and 8 postpartum. Ind = individual. 
during a period of increasing EB. Animals allocated to the individual cow treatment attained a positive EB at wk 4 postpartum, whereas those allocated to the control, high-starch/high-fat, and low-protein treatments attained a positive EB in wk 5, 8, and 8, respectively. Beam and Butler $(1997,1999)$ suggested that follicles emerging after, rather than before, the EB nadir are more likely to ovulate because of the increase in $\mathrm{LH}$ pulse frequency, which is evident after the EB nadir (Diskin et al., 2003). Despite the apparent advantages and benefits, it is acknowledged that managing cows on an individual basis to improve EB may prove difficult to implement in practice on-farm.

\section{Onset of Luteal Activity}

There were no statistically significant treatment effects on the interval to OLA in the current study. However, the mean interval $(35.3 \mathrm{~d})$ was longer than previously reported: 27.0 d by Darwash et al. (1997); 27.9 d by Royal et al. (2000); 30.1 d by McCoy et al. (2006); and 32.2 d by Law et al. (2009c). This chronological progression suggests that the interval to OLA is continuously increasing. Increases in time to OLA may reflect the inability of the ovulatory follicle to produce sufficient estradiol to facilitate ovulation in the early postpartum period and may be related to the degree of negative DEB (as previously stated). Short intervals from calving to OLA increase the potential number of estrous cycles preceding insemination and improves conception rate (Butler, 2003). Conception rate to first service in the current study (mean 30.5\%) was lower than reported previously. Lamming and Darwash (1998), found a CR of $60.9 \%$ in cows with normal progesterone profiles and $43.7 \%$ in those with atypical profiles. Royal et al. (2000) reported a CR of $39.7 \%$, whereas Mayne et al. (2002) reported a value of $37.1 \%$. The current value was close to that of $30.7 \%$ reported by Law et al. (2009c). Trends observed between 1998 and 2009 suggest a continuation in the decrease in CR to first service of $1 \%$ per year, as calculated by Royal et al. (2000).

\section{Progesterone Profiles}

In the current study, $62.2 \%$ of cows exhibited at least one atypical progesterone profile. This figure is higher than that (42.1\%) reported by McCoy et al. (2006) but similar to the figure of $62 \%$ reported by Law et al. (2009c) Similarly, Royal et al. (2000) reported that the proportion of cows exhibiting at least 1 atypical cycle had increased from 31.7 to $43.7 \%$ between 2 databases collated for the periods 1975 to 1982 and 1995 to 1998, respectively. Delayed ovulation occurred in $28 \%$ of all cycles, as reflected in a prolonged ILI (Royal et al., 2000). In the current study, the incidence of DOV I $(12.5 \%)$ was lower than reported in many recent studies but within the range of values reported since 1998 (11\% by Lamming and Darwash, $1998 ; 12.9 \%$ by Royal et al., $2000 ; 17.4 \%$ by McCoy et al., 2006 ; and $20.7 \%$ by Law et al., 2009c). The incidence of DOV II (16.3\%) was comparable to previously published values of $13 \%$ by Lamming and Darwash (1998), $16 \%$ by Royal et al. (2000), and $28 \%$ by Law et al. (2009c). Delayed ovulation may be caused by a delay in, or failure of, the surge in circulating concentrations of LH, which causes thinning and subsequent rupture of the follicle wall, leading to ovulation. In their review, Peter et al. (2009) attributed DOV II to the insensitivity of the hypothalamus to positive feedback by estradiol or to altered follicular responsiveness to gonadotropic support, mediated via metabolic hormones such as IGF-1 and insulin (Beam and Butler, 1999). Delayed ovulation type II also may occur when incomplete luteolysis of the corpus luteum from the previous cycle occurs or where a continuing luteinized ovarian structure is present (Lee et al., 1985; Sirois and Fortune, 1990; Silvia et al., 2002; Sartori et al., 2004).

The incidence of PCL I in the current study was $16.4 \%$, which is comparable to values of $16.0,19.0$, and 19.0\% from Taylor et al. (2003), McCoy et al. (2006), and Law et al. (2009c), respectively. The incidence of PCL II (34.4\%) was unexpectedly high when compared with previously published work, which showed values of 6.35\% (Lamming and Darwash, 1998), 6.4 and 16.8\% in 1975 to 1982 and 1995 to 1998, respectively (Royal et al., 2000), 11\% (Taylor et al., 2003), 11.9\% (McCoy et al., 2006), and 20.7\% (Law et al., 2009c).

Persistent corpora lutea are mostly associated with 3 occurrences: 1) when embryonic loss occurs following maternal recognition of pregnancy; 2) when luteolysis is delayed in the absence of pregnancy, and 3) when an estradiol-producing dominant follicle is absent at the time of luteal regression (Peter et al., 2009). Delayed luteolysis may occur as a result of a suboptimal uterine environment that disrupts normal hormonal and luteolytic mechanisms (Kindahl et al., 1999; Sheldon et al. 2006). Sheldon et al. (2006) illustrated that uterine infection can increase prostaglandin $\mathrm{E}_{2}\left(\mathrm{PGE}_{2}\right)$ as a result of a stimulatory effect of LPS found on the uterine pathogen Escherichia coli. Elevated $\mathrm{PGE}_{2}$ has a luteotrophic effect, which increases progesterone secretion and, subsequently, prolongs the luteal phase. Under normal, optimal uterine conditions, prostaglandin F2 $\alpha$ from the uterus acts on the corpus luteum and causes it to regress and cease progesterone production, removing the inhibitory effect on LH release and allowing the next ovulation to occur (Law et al., 2009c). The 
Table 10. Dependability of estrous behaviors

\begin{tabular}{|c|c|c|c|c|}
\hline Item & Sniffing & $\begin{array}{l}\text { Chin } \\
\text { resting }\end{array}$ & Mounting & $\begin{array}{c}\text { Standing } \\
\text { heat }\end{array}$ \\
\hline Reliability $^{1}$ & 84.6 & 85.2 & 87.6 & 100.0 \\
\hline Percentage expression $^{2}$ & 88.1 & 89.0 & 81.6 & 47.4 \\
\hline Dependability $^{3}$ & 7,456 & 7,587 & 7,149 & 4,736 \\
\hline
\end{tabular}

absence of an estradiol-producing dominant follicle at the time of luteal regression results in the suppression of the pulsatile release of PGF2 $\alpha$ and, subsequently, luteolysis (Knickerbocker et al., 1986; Thatcher et al., 1989; McCracken et al., 1999).

Extended IOI is evident in animals with cycles exhibiting PCL II or DOV II. In the current study, no statistically significant treatment effects on the incidence of IOI were observed and the overall mean was 22.7 d. However, the mean IOI in animals allocated to the individual cow management treatment was $23.9 \mathrm{~d}$. According to Royal et al. (2000), IOIs outside the range 19 to $23 \mathrm{~d}$ are associated with decreased fertility. In the current study, $36 \%$ of cycles had an IOI greater $23 \mathrm{~d}$, whereas $27 \%$ were shorter than $19 \mathrm{~d}$.

In the current study, cows failing to conceive to first or second inseminations had a longer luteal phase in the first cycle postpartum. The luteal phase is generally shorter in the first cycle than in subsequent cycles due to the premature release of $\mathrm{PGF}_{2 \alpha}$ (Peter et al., 1989) in response to the increased estradiol produced from formation of the post-ovulatory dominant follicle (Crowe, 2008). Furthermore, animals failing to conceive to the first insemination or not pregnant by $100 \mathrm{~d}$ after commencement of breeding, had a longer IOI in the second cycle postpartum and a longer ILI in the third cycle postpartum. Using the IOI limits set by Royal et al. (2000), $63 \%$ of the cycles in the current study were associated with decreased fertility. In concurrence, the results from the current study confirm that irregularities in estrous cycles have detrimental effects on fertility.

\section{The Expression and Detection of Estrous Behavior}

Efficient estrous detection is essential to increasing the reproductive performance of dairy cows. In the current study, treatments had no statistically significant effect on behavioral expression during estrus or on the total estrous score calculated for successive observations. The most commonly expressed estrous behaviors were chin-resting (89.0\%), sniffing the vagina of another cow $(88.1 \%)$, and mounting or attempting to mount another cow (81.6\%; Table 10). The most reliable estrous behaviors, when expressed, were standing immobile upon being mounted by another cow (100.0\%), mounting or attempting to mount another cow $(87.6 \%)$, chinresting $(85.2 \%)$, and sniffing the vagina of another cow $(84.6 \%)$.

Van Vliet and Van Eerdenburg (1996) conducted 30 min of observation of cows every $2 \mathrm{~h}$ and found that only $37 \%$ of estrous cycles were characterized by standing immobile on being mounted. Using the same protocol, Lyimo et al. (2000) observed that $53 \%$ of estrous cycles were characterized by standing immobile on being mounted. Standing immobile on being mounted was expressed in $47.4 \%$ of cycles in the current study when observed twice daily for $30 \mathrm{~min}$. This is lower than previously reported $(51.7 \%$ ) by Law et al. (2009b), who also observed animals twice daily for $30 \mathrm{~min}$. Standing immobile on being mounted has long been recognized as the primary and most reliable sign of estrus and the best indicator of the cow's preovulatory state (Hafez, 1969). However, the expression of standing immobile on being mounted appears to have decreased in the modern high-yielding dairy cow and may no longer be a dependable behavior in defining estrus on modern dairy herds where labor and time resources are limiting (Law et al., 2009b). In the current study, dependability was calculated according to Law et al. (2009b). Our data suggest that the most dependable behaviors as indicators of estrus are chin-resting and sniffing the vagina of another cow, whereas standing immobile on being mounted was ranked only fourth in terms of dependable behavior.

The number of animals in estrus simultaneously (the sexually active group) is known to affect the expression of estrous behavior (Van Eerdenburg et al., 1996; Law et al., 2009b). In the current study, as the size of the sexually active group increased, the expression of mounting or attempting to mount another cow, and the total estrous score, also increased. The behavior of standing immobile on being mounted was expressed significantly more when 2 or more animals were in es- 
trus simultaneously. Roelofs et al. (2005) found that chin-resting and mounting or attempting to mount another cow was expressed less frequently when one animal was in estrus compared with when 2 or more animals were in estrus simultaneously.

The expression of estrus is positively correlated with, and is largely controlled by, plasma estradiol concentration (Lyimo et al., 2000). Larger pre-ovulatory follicles have been associated with higher estradiol concentrations, which potentially increase the intensity of estrous expression (Lyimo et al., 2000). However, Lopez et al. (2004) reported that high-yielding dairy cows had lower estradiol concentrations compared with lower-yielding dairy cows despite having larger preovulatory follicles. All animals in the current study were high-yielding dairy cows and ovarian activity was not measured. However, animals that became pregnant had a significantly higher total estrous score in the cycle of conception, which may result from increased estradiol concentrations and the subsequent LH surge, inducing ovulation. Parity had no statistically significant effect on the total estrous score, but multiparous cows tended to achieve higher total estrous scores than did primiparous cows.

\section{CONCLUSIONS}

None of the nutritional regimens or interventions applied in the current study had a statistically significant effect on the reproductive performance of the highyielding Holstein-Friesian dairy cows. However, with larger numbers, significance may have been achieved and verified the observed trends: improved ovarian activity in animals offered the high-/low-starch diet and improved energy balance and subsequent fertility in cows managed on an individual basis. Managing the nutrition of cows so as to adjust individual milk yields resulted in a more energetically uniform group of cows at the commencement of breeding. Attention to detail is needed in detecting estrus in high-yielding dairy cows, as standing heat (the most commonly used pre-ovulatory indicator) was expressed in only $47.4 \%$ of the estrous cycles. Secondary behaviors, such as sniffing the vagina and chin-resting, were more frequently expressed and we suggest that these behaviors should be incorporated into heat detection protocols. The findings from this study re-emphasize the complex and multifactorial nature of the reproductive cycle in modern high-yielding Holstein-Friesian cows.

\section{REFERENCES}

Adamiak, S. J., K. Mackie, R. G. Watt, R. Webb, and K. D. Sinclair. 2005. Impact of nutrition on oocyte quality: Cumulative effects of body composition and diet leading to hyperinsulinemia in cattle. Biol. Reprod. 73:918-926.
Adamiak, S. J., K. Powell, J. A. Rooke, R. Webb, and K. D. Sinclair. 2006. Body composition, dietary carbohydrates and fatty acids determine post-fertilisation development of bovine oocytes in vitro. Reproduction 131:247-258.

Beam, S. W., and W. R. Butler. 1997. Energy balance and ovarian follicle development prior to the first ovulation postpartum in dairy cows receiving three levels of dietary fat. Biol. Reprod. $56: 133-142$.

Beam, S. W., and W. R. Butler. 1999. Effects of energy balance on follicular development and first ovulation in post partum dairy cows. J. Reprod. Fertil. 54(Suppl.):411-424.

Britt, J. H. 1992. Impacts of early postpartum metabolism on follicular development and fertility. Pages 39-43 in 25th Proc. Ann. Conf. Am. Assoc. Bovine Pract., St Paul, MN. Am. Assoc. Bovine Pract., Auburn, AL.

Butler, W. R. 2001. Nutritional effects on resumption of cyclicity and conception rate in postpartum dairy cows. Anim. Sci. Occas. Publ. 26:133-145.

Butler, W. R. 2003. Energy balance relationships with follicular development, ovulation and fertility in postpartum dairy cows. Livest. Prod. Sci. 83:2-3., 211-218.

Butler, W. R., J. J. Calaman, and S. W. Beam. 1996. Plasma and milk urea nitrogen in relation to pregnancy rate in lactating dairy cattle. J. Anim. Sci. 74:858-865.

Butler, W. R., R. W. Everett, and C. E. Coppock. 1981. The relationships between energy balance, milk production and ovulation in postpartum Holstein cows. J. Anim. Sci. 53:742-748.

Childs, S., A. A. Hennessy, J. M. Sreenan, D. C. Wathes, Z. Cheng, C. Stanton, M. G. Diskin, and D. A. Kenny. 2008. Effect of level of dietary n-3 polyunsaturated fatty acid supplementation on systemic and tissue fatty acid concentrations and on selected reproductive variables in cattle. Theriogenology 70:595-611.

Crowe, M. A. 2008. Resumption of ovarian activity in post-partum beef and dairy cows. Reprod. Domest. Anim. 43(Suppl. 5):20-28.

Cushnahan, A., and F. J. Gordon. 1995. The effects of grass preservation on intake, apparent digestibility and rumen degradation characteristics. Anim. Sci. 60:429-438.

Darwash, A. O., G. E. Lamming, and J. A. Woolliams. 1997. The phenotypic association between the interval to post-partum ovulation and traditional measures of fertility in dairy cattle. Anim. Sci. 65:9-16.

Diskin, M. G., D. R. Mackey, J. F. Roche, and J. M. Sreenan. 2003. Effects of nutrition and metabolic status on circulating hormones and ovarian follicle development in cattle. Anim. Reprod. Sci. $78: 345-370$.

Domecq, J. J., A. L. Skidmore, J. W. Lloyd, and J. B. Kaneene. 1997. Relationship between body condition score and conception at first artificial insemination in a large dairy herd of high yielding Holstein cows. J. Dairy Sci. 80:113-120.

Edmonson, A. J., I. J. Lean, L. D. Weaver, T. Farver, and G. Webster. 1989. A body condition scoring chart for Holstein dairy cows. J. Dairy Sci. 72:68-78

FAWC (Farm Animal Welfare Council). 1997. Page 96 in Report on the Welfare of Dairy Cattle. Farm Animal Welfare Council, Surrey, UK.

Fouladi-Nashta, A. A., C. G. Gutierrez, P. C. Garnsworthy, and R. Webb. 2005. Effects of dietary carbohydrate source on oocyte/ embryo quality and development in high-yielding, lactating dairy cattle. In Proc. Soc. Study Reprod. 38th Annual Meeting, Quebec City, Quebec, Canada. Soc. Study Reprod., Madison, WI.

Fouladi-Nashta, A. A., C. G. Gutierrez, J. G. Gong, P. C. Garnsworthy, and R. Webb. 2007. Impact of dietary fatty acids on oocyte quality and development in lactating dairy cows. Biol. Reprod. 77:9-17.

Garnsworthy, P. C., A. A. Fouladi-Nashta, G. E. Mann, K. D. Sinclair and R. Webb. 2009. Effect of dietary-induced changes in plasma insulin concentrations during the early postpartum period on pregnancy rate in dairy cows. Reproduction 137:759-768.

Garnsworthy, P. C., A. Lock, G. E. Mann, K. D. Sinclair, and R. Webb. 2008a. Nutrition, metabolism and fertility in dairy cows: 
1. Dietary energy source and ovarian function. J. Dairy Sci. 91:3814-3823.

Garnsworthy, P. C., A. Lock, G. E. Mann, K. D. Sinclair, and R. Webb. 2008b. Nutrition, metabolism, and fertility in dairy cows: 2 . Dietary fatty acids and ovarian function. J. Dairy Sci. 91:38243833.

Gong, J. G., W. J. Lee, P. C. Garnsworthy, and R. Webb. 2002. Effect of dietary-induced increases in circulating insulin concentrations during the early postpartum period on reproductive function in dairy cows. Reproduction 123:419-427.

Grummer, R. R., and D. J. Carroll. 1988. A review of lipoprotein cholesterol metabolism: Importance to ovarian function. J. Anim. Sci. 66:3160-3173.

Hafez, E. S. E. 1969. The Behaviour of Domestic Animals. 2nd ed. Bailliere Tindall, London, UK.

Jolly, P. D., S. McDougall, L. A. Fitzpatrick, K. L. Macmillan, and K. W. Entwistle. 1995. Physiological effects of undernutrition on postpartum anoestrus in dairy cows. J. Reprod. Fertil. Suppl. 49:477-492.

Jorritsma, R., T. Wensing, T. A. M. Kruip, P. L. A. M. Vos, and J. P. T. M. Noordhuizen. 2003. Metabolic changes in early lactation and impaired reproductive performance in dairy cows. Vet. Res. $34: 11-26$.

Kerbrat, S., and C. Disenhaus. 2004. A proposition for an updated behavioral characterization of the estrous period in dairy cows. Appl. Anim. Behav. Sci. 87:223-238.

Kindahl, H., M. Bekena, K. Kask, K. Königsson, H. Gustafsson, and K. Odensvik. 1999. Endocrine aspects of uterine involution in the cow. Reprod. Domest. Anim. 34:261-268.

Knickerbocker, J. J., W. W. Thatcher, F. W. Bazer, M. Drost, D. H. Barron, K. B. Fincher, and R. M. Roberts. 1986. Proteins secreted by day-16 to -18 bovine conceptuses extend corpus luteum function in cows. J. Reprod. Fertil. 77:381-391.

Lamming, G. E., and A. O. Darwash. 1998. The use of milk progesterone profiles to characterize components of subfertility in milked dairy cows. Anim. Reprod. Sci. 52:175-190.

Law, R. A., F. J. Young, D. C. Patterson, D. J. Kilpatrick, A. R. G. Wylie, and C. S. Mayne. 2009a. Effect of dietary protein content on animal production and blood metabolites of dairy cows during lactation. J. Dairy Sci. 92:1001-1012.

Law, R. A., F. J. Young, D. C. Patterson, D. J. Kilpatrick, A. R. G. Wylie, and C. S. Mayne. 2009b. Effect of dietary protein content in estrous behavior of dairy cows during early and mid lactation. J. Dairy Sci. 92:1013-1022.

Law, R. A., F. J. Young, D. C. Patterson, D. J. Kilpatrick, A. R. G. Wylie, and C. S. Mayne. 2009c. Effect of dietary protein content on the fertility of dairy cows during early and mid lactation. J. Dairy Sci. 92:2737-2746.

Lee, C. N., J. K. Critser, and R. L. Ax. 1985. Changes of luteinizing hormone and progesterone for dairy cows after gonadotropinreleasing hormone at first postpartum breeding. J. Dairy Sci. 68:1463-1470.

Leroy, J. L. M. R., V. Van Hoeck, M. Clemente, D. Rizos, A. Gutierrez-Adan, A. Van Soom, M. Uytterhoeven, and P. E. J. Bols. 2010 The effect of nutritionally induced hyperlipidaemia on in vitro bovine embryo quality. Hum. Reprod. 25:768-778.

Lopez, H., L. D. Satter, and M. C. Wiltbank. 2004. Relationship between level of milk production and estrous behavior of lactating dairy cows. Anim. Reprod. Sci. 81:209-223.

Lucy, M. C., C. R. Staples, F. M. Michel, and W. W. Thatcher. 1991. Energy balance and size and number of ovarian follicles detected by ultrasonography in early postpartum dairy cows. J. Dairy Sci. $74: 473-482$.

Lyimo, Z. C., M. Nielen, W. Ouweltjes, T. A. M. Kruip, and F. J. C. M. van Eerdenburg. 2000. Relationship among estradiol, cortisol and intensity of estrous behavior in dairy cattle. Theriogenology 53:1783-1795.

Maas, J. A., P. C. Garnsworthy, and A. P. F. Flint. 2009. Modelling responses to nutritional, endocrine and genetic strategies to increase fertility in the UK dairy herd. Vet. J. 180:356-362.
Mackey, D. R., J. M. Sreenan, J. F. Roche, and M. G. Diskin. 1999. The effect of acute nutritional restriction on incidence of anovulation and periovulatory estradiol and gonadotropin concentrations in beef heifers. Biol. Reprod. 61:1601-1607.

Mayne, C. S., D. R. Mackey, M. Verner, W. J. McCaughey, F. J. Gordon, M. A. McCoy, S. D. Lennox, D. C. Catney, A. R. G. Wylie, and B. W. Kennedy. 2002. Fertility of dairy cows in Northern Ireland. Vet. Rec. 150:707-713.

McCoy, M. A., S. D. Lennox, C. S. Mayne, W. J. McCaughey, H. W. J. Edgar, and A. W. Gordon. 2006. Milk progesterone profiles and their relationship with fertility, production and disease in dairy herds in Northern Ireland. Anim. Sci. 82:213-222.

McCracken, J. A., E. E. Custer, and J. C. Lamsa. 1999. Luteolysis: A neuroendocrine-mediated event. Physiol. Rev. 79:263-323.

Morris, T. R. 2002. Experimental design and analysis in animal sciences. CABI Publishing, Oxon, UK.

Newbold, J. 2006. Declining fertility: is the liver to blame? Pages 1519 in Proceedings of the Nottingham Cattle Fertility Conference 2006, Nottingham, UK.

Park, R. S., R. E. Agnew, F. J. Gordon, and R. W. J. Steen. 1998. The use of near infrared reflectance spectroscopy (NIRS) on undried samples of grass silage to predict chemical composition and digestibility parameters. Anim. Feed Sci. Technol. 72:155-167.

Payne, R. W., D. A. Murray, S. A. Harding, D. B. Baird, and D. M. Soutar. 2007. GenStat for Windows. 10th ed. Introduction. VSN International, Hemel Hempstead, Hertfordshire, UK.

Peter, A. T., W. T. Bosu, R. M. Liptrap, and E. Cummings. 1989. Temporal changes in serum prostaglandin $\mathrm{F}$ (2alpha) and oxytocin in dairy cows with short luteal phases after the first postpartum ovulation. Theriogenology 32:277-284.

Peter, A. T., P. L. A. M. Vos, and D. J. Ambrose. 2009. Postpartum anestrus in dairy cattle. Theriogenology 71:1333-1342.

Porter, M. G. 1992. Comparison of sample preparation methods for the determination of the gross energy concentration of fresh silage. Anim. Feed Sci. Technol. 37:201-208.

Porter, M. G., and R. S. Murray. 2001. The volatility of components of grass silage on oven drying and the inter-relationship between dry matter content estimated by different analytical methods. Grass Forage Sci. 56:405-411.

Reimers, T. J., R. D. Smith, and S. K. Newman. 1985. Management factors affecting reproductive performance of dairy cows in the north-eastern United States. J. Dairy Sci. 68:963-972.

Roelofs, J. B., F. J. C. M. van Eerdenburg, N. M. Soede, and B. Kemp. 2005. Various behavioral signs of estrous and their relationship with time of ovulation in dairy cattle. Theriogenology 63:1366-1377.

Roth, Z., R. Meidan, A. Shaham-Albalancy, R. Braw-Tal, and D. Wolfenson. 2001. Delayed effect of heat stress on steroid production in medium-sized and preovulatory bovine follicles. Reproduction 121:745-751.

Royal, M. D., A. O. Darwash, A. P. F. Flint, R. Webb, J. A. Woolliams, and G. E. Lamming. 2000. Declining fertility in dairy cattle: Changes in traditional and endocrine parameters of fertility. Anim. Sci. 70:487-501.

Sartori, R., J. M. Haughian, R. D. Shaver, G. J. M. Rosa, and M. C. Wiltbank. 2004. Comparison of ovarian function and circulating steroids in estrous cycles of Holstein heifers and lactating cows. J. Dairy Sci. 87:905-920.

Sauer, M. J., J. A. Foulkes, A. Worsfold, and B. A. Morris. 1986. Use of progesterone 11-glucuronide-alkaline phosphatase conjugate in a sensitive microtitre-plate enzyme-immunoassay of progesterone in milk and its application to pregnancy testing in dairy cattle. J. Reprod. Fertil. 76:375-391.

Schauff, D. J., and J. H. Clark. 1992. Effects of feeding diets containing calcium salts of long-chain fatty acids to lactating dairy cows. J. Dairy Sci. 75:2990-3002.

Sheldon, I. M., G. S. Lewis, S. LeBlanc, and R. O. Gilbert. 2006 Defining postpartum uterine disease in cattle. Theriogenology 65:1516-1530. 
Silvia, W. J., T. B. Hatler, A. M. Nugent, and L. F. Laranja de Fonseca. 2002. Ovarian follicular cysts in dairy cows: An abnormality in folliculogenesis. Domest. Anim. Endocrinol. 23:167-177.

Sirois, J., and J. E. Fortune. 1990. Lengthening the bovine estrous cycle with low levels of exogenous progesterone: a model for studying ovarian follicular dominance. Endocrinology 127:916-925.

Staples, C. R., J. M. Burke, and W. W. Thatcher. 1998. Influence of supplemental fats on reproductive tissues and performance of lactating cows. J. Dairy Sci. 81:856-871.

Steen, R. W. J. 1989. A comparison of soya-bean, sunflower and fish meals as protein supplements for yearling cattle offered grass silage-based diets. Anim. Prod. 48:81-89.

Taylor, V. J., D. E. Beever, M. J. Bryant, and D. C. Wathes. 2003. Metabolic profiles and progesterone cycles in first lactation dairy cows. Theriogenology 59:1661-1677.

Thatcher, S. S., E. Jones, and A. H. DeCherney. 1989. Ovarian cysts decrease the success of controlled ovarian stimulation and in vitro fertilization. Fertil. Steril. 52:812-816.

Thomas, C. 2004. Feed Into Milk: An Advisory Manual. Nottingham University Press, Nottingham, UK.
Thrusfield, M. 2005. Veterinary Epidemiology. 3rd ed. Blackwell Science Ltd., Oxford, UK.

Van Eerdenburg, F. J. C. M., H. S. H. Loeffler, and J. H. van Vliet. 1996. Detection of estrus in dairy cows: A new approach to an old problem. Vet. Q. 18:52-54.

van Knegsel, A. T. M., H. van den Brand, J. Dijkstra, W. M. van Straalen, R. Jorritsma, S. Tamminga, and B. Kemp. 2007a. Effect of glucogenic vs. lipogenic diets on energy balance, blood metabolites, and reproduction in primiparous and multiparous dairy cows in early lactation. J. Dairy Sci. 90:3397-3409.

van Knegsel, A. T. M., H. van den Brand, E. A. Grant, J. Dijkstra, R. Jorritsma, E. Decuypere, S. Tamminga, and B. Kemp. 2007b. Dietary energy source in dairy cows in early lactation: Metabolites and metabolic hormones. J. Dairy Sci. 90:1477-1485.

Van Vliet, J. H., and F. J. C. M. Van Eerdenburg. 1996. Sexual activities and oestrous detection in lactating Holstein cows. Appl. Anim. Behav. Sci. 50:57-69. 